\title{
24. SURVEYS AND SELECTION OF SITES 338, 339, 340, 341, 342, AND 343 ON THE VQRING PLATEAU
}

\author{
M. Talwani, Lamont-Doherty Geological Observatory of Columbia University, Palisades, New York
}

The V $\phi$ ring Plateau is an important feature of the Norwegian Continental Margin. The bathymetric chart (Figure 1) based primarily on Vema surveys during Cruises 23, 27, 28, and 30 shows the submarine V $\phi$ ring Plateau. The minimum depth at the top of the plateau lies between 1200 and 1300 meters. To the southwest it is separated from the Norway Basin by the Jan Mayen Fracture Zone. The Lofoten Basin lies to the north of the V $\phi$ ring Plateau.

The V $\phi$ ring Plateau is divided into two parts, the Inner V $\phi$ ring Plateau and the Outer V $\phi$ ring Plateau by the buried V $\phi$ ring Plateau escarpment (Talwani and Eldholm, 1972). The Outer V $\phi$ ring Plateau is characterized by sea-floor-spreading-type magnetic lineations (Figure 2). Anomaly 23 is situated near the base of the plateau; anomaly 24 is close to, but runs across, the 1500 meter isobath. Anomaly 25 is not seen on the V $\phi$ ring Plateau which led Talwani and Eldholm (in press) to suggest that the opening of the Norwegian Sea started in the time between anomaly 24 and anomaly 25 , a time of reversed magnetic polarity. The negative anomaly immediately seaward of the V $\phi$ ring Plateau escarpment (marked NEG in Figure 2) is interpreted as an edge effect arising from juxtaposition of these reversely magnetized rocks seaward of the escarpment with the very weakly magnetized (continental) basement landward of the escarpment.

A magnetic quiet zone exists over the Inner $\mathrm{V} \phi$ ring Plateau (Figure 2). Talwani and Eldholm (1972) have suggested that this is an area of subsided continental crust.

Three single-channel seismic reflection profiles are shown in Figure 3. Location of these profiles is given in Figures 1 and 2 . The profiles typify the shallow seismic structure of the V $\phi$ ring Plateau. Seaward of the escarpment there exists a very prominent seismic reflector. The thickness of sediments above this reflector is small, generally under $1 \mathrm{sec}$ of double reflection time. Close to the escarpment no distinct reflector is seen above the prominent one; however, some distance seaward an intermediate reflector (and in the case of profile E-F, several reflectors) appear above the prominent one. The latter cannot be followed east of the escarpment. Sonobuoy refraction profiles over a large part of the Outer V $\phi$ ring Plateau associate a velocity of about 5 $\mathrm{km} / \mathrm{sec}$ with the prominent reflector. Talwani and Eldholm (1972) suggested this to be basement and the overlying sediments, which have a velocity in the neighborhood of $2 \mathrm{~km} / \mathrm{sec}$, are believed to be Tertiary.

The Inner V $\phi$ ring Plateau lying east of the escarpment, contains a large thickness of sediments and basement is not seen on the seismic reflection profiles. Various sedimentary layers are seen underneath the V $\phi$ ring Plateau on Profiles A-B and C-D. The second multiple bottom reflection, however, obscures the deeper sedimentary reflectors. Under the Inner V $\phi$ ring Plateau, sonobuoy seismic refraction profiles reveal various layers, with velocities up to about $4.5 \mathrm{~km} / \mathrm{sec}$. Talwani and Eldholm (1972) believe that a thick section of sediments lies here, and by comparison of sedimentary velocities with those on the Norwegian Shelf and the North Sea, where drilling has been carried out, believe that a succession of sediments as old as Mesozoic, or perhaps even Paleozoic, underlies the Inner V $\phi$ ring Plateau.

Diapiric bodies are barely visible on section C-D on the Inner Voring Plateau; confidence that these are indeed diapirs comes from a study of piston cores taken over them. They contain a middle-Eocene fauna (Bjфrklund and Kellogg, 1972). Sites 339 and 340 were located on top of the diapirs in an effort to obtain older material; Site 341 was located in the area between the diapirs and the escarpment to sample the normal sedimentary succession on the V $\phi$ ring Plateau. Sites 338,342 , and 343 were located on the Outer V $\phi$ ring Plateau for the purpose of samples of the prominent reflector as well as of the sediments lying above it.

\section{ACKNOWLEDGMENTS}

Support for this work came from Contracts N00014-67-A0108-0004 and N00014-75-C-0210 with the U.S. Office of Naval Research and from Grants GA1434, GP5392, GA17731, GA27281, and DES71-00214-A07 from the National Science Foundation.

\section{REFERENCES}

Bjфrklund, K.R. and Kellogg, D.E., 1972. Five new Eocene radiolarian species from the Norwegian Sea: Micropaleontology, v. 18 , p. $386-396$.

Talwani, M. and Eldholm, O., 1972. The continental margin off Norway: A geophysical study: Geol. Soc. Am. Bull., v. 83 , p. $3575-3608$.

in press. Evolution of the Norwegian-Greenland Sea: Geol. Soc. Am. Bull. 


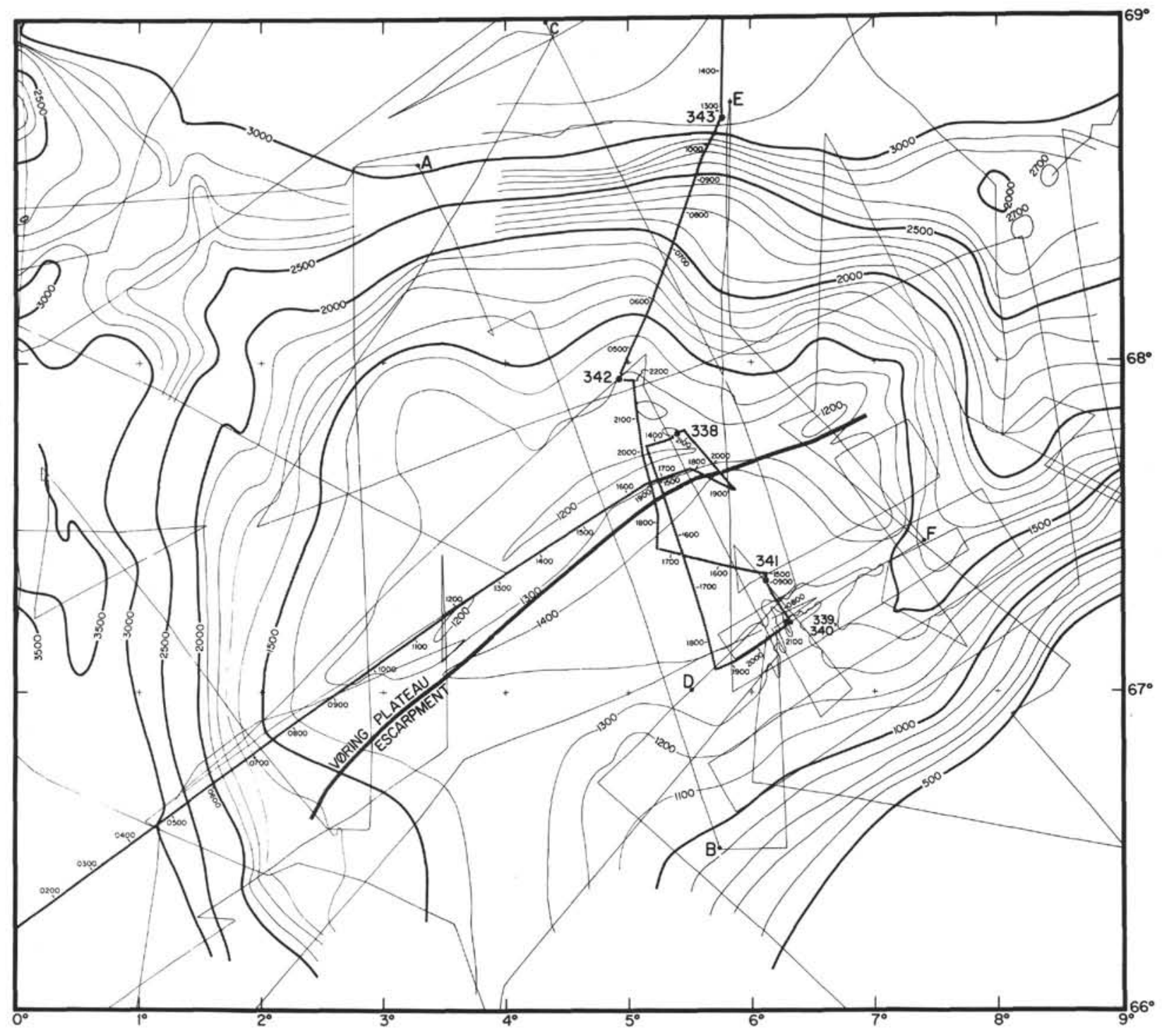

Figure 1. Bathymetric map in corrected meters of the Voring Plateau Escarpment and the track of Glomar Challenger with the drill sites shown. Other tracks were made by Vema which provided the necessary site survey information. 


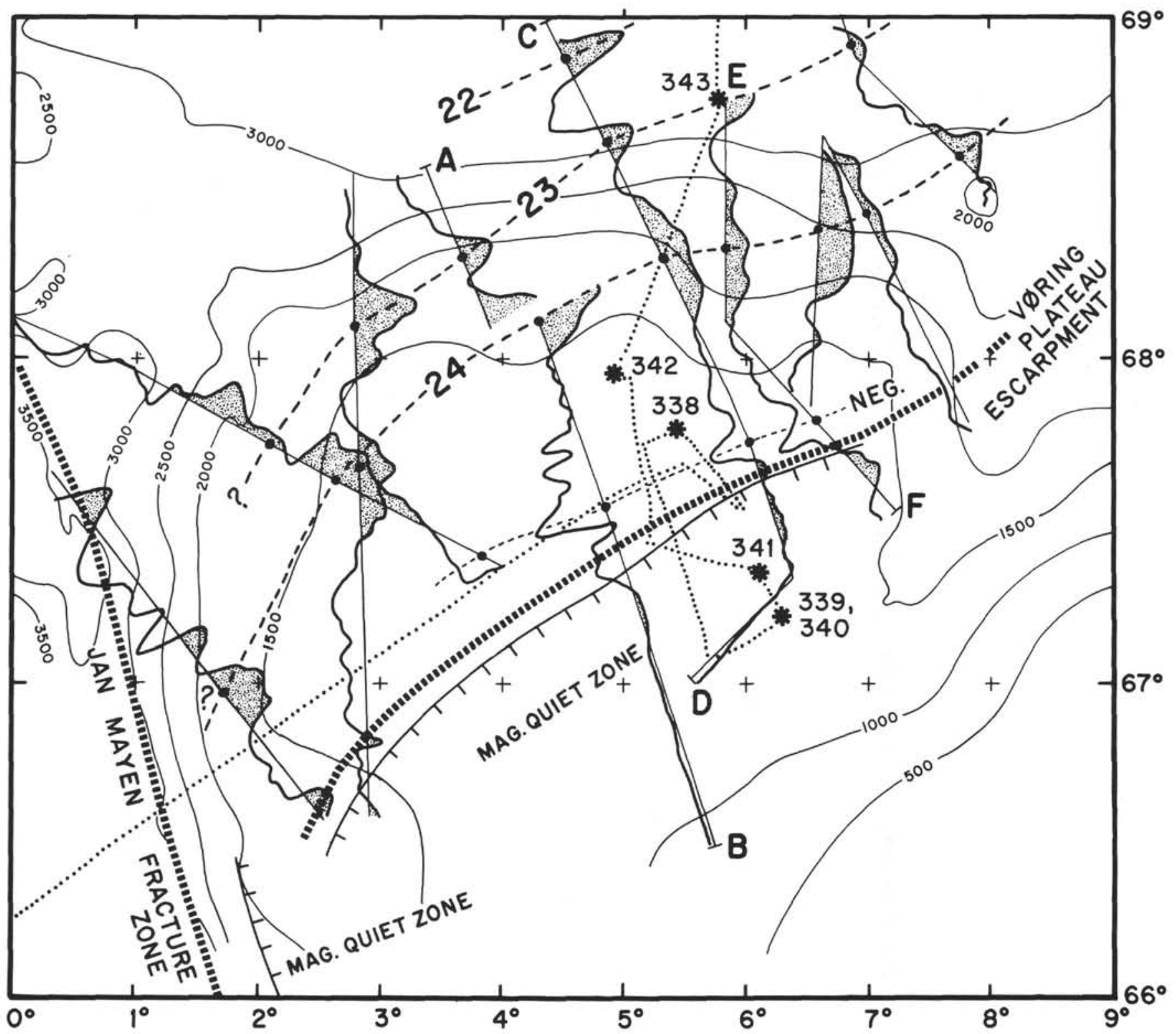

Figure 2. Selected magnetic profiles in the Voring Plateau. Note that Anomaly 24 is close to but runs across the $1500 \mathrm{~m}$ isobath. Positive magnetic anomalies are shaded. Site 343 is located on magnetic anomaly 23, Sites 342 and 338 are located between anomaly 24 and the Voring Plateau escarpment. 

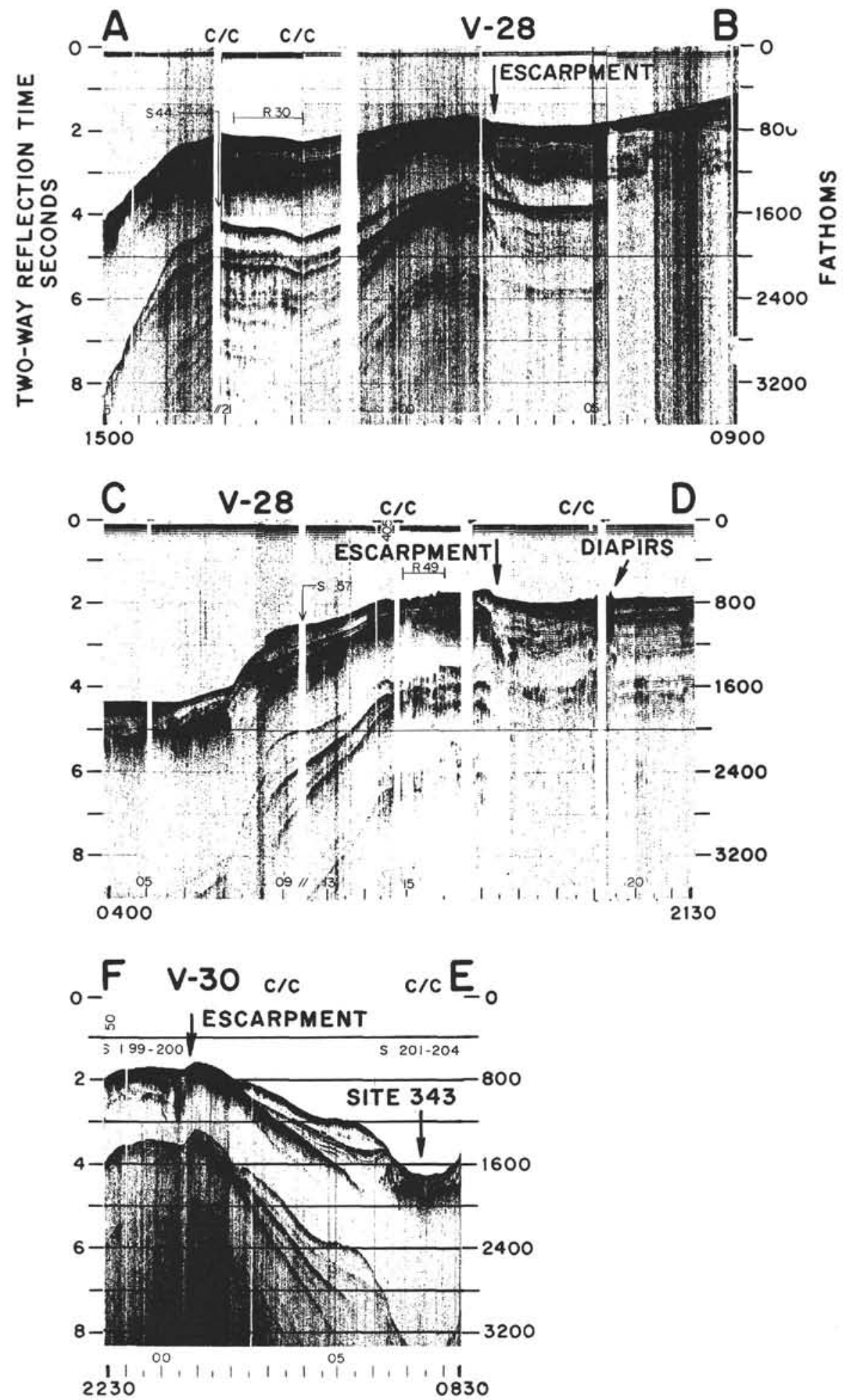

Figure 3. Selected seismic reflection profiles across the Voring Plateau escarpment made by the single channel seismic reflection equipment during Vema Cruises 28 and 30 . 